\author{
Asian Journal of \\ Medical and Biological Research \\ ISSN 2411-4472 (Print) 2412-5571 (Online) \\ www.ebupress.com/journal/ajmbr
}

\title{
Article \\ Moringa leaf extract as a bio-stimulant on growth, yield and nutritional improvement in cabbage
}

\author{
Tahsina Sharmin Hoque ${ }^{1}$, Md. Sohel Rana ${ }^{1}$, Shahana Akter Zahan ${ }^{2}$, Israt Jahan ${ }^{1}$ and Md. Anwarul Abedin ${ }^{*}$ \\ ${ }^{1}$ Department of Soil Science, Bangladesh Agricultural University, Mymensingh, Bangladesh \\ ${ }^{2}$ Ministry of Public Administration, Dhaka, Bangladesh
}

*Corresponding author: Professor Dr. Md. Anwarul Abedin, Laboratory of Environment and Sustainable Development, Department of Soil Science, Bangladesh Agricultural University, Mymensingh, Bangladesh. Phone: +8801718031462; E-mail: m.a.abedin@bau.edu.bd

Received: 20 April 2020/Accepted: 18 June 2020/ Published: 30 June 2020

\begin{abstract}
Moringa is a valuable plant whose leaves are enriched with antioxidants, amino acids, vitamins and mineral nutrients and can be used as a bio-stimulant. A field work was conducted at the Soil Science Field Laboratory of Bangladesh Agricultural University (BAU), Mymensingh, during rabi season from November 2017 to February 2018 in order to investigate the effect of moringa leaf extract (MLE) on growth, yield and nutrient status of cabbage. The experiment was laid out in a randomized complete block design with four treatments and three replications. The treatments were $\mathrm{T}_{1}$ (control), $\mathrm{T}_{2}$ (MLE) sprayed at 2 weeks after transplanting only], $\mathrm{T}_{3}$ (MLE sprayed at 2 weeks and 4 weeks after transplanting), $\mathrm{T}_{4}$ (MLE sprayed at 2 weeks after transplanting and after every two weeks thereafter). The rate of MLE application was $25 \mathrm{~mL} \mathrm{plant}^{-1}$. All the treatments received recommended dose of $\mathrm{N}, \mathrm{P}, \mathrm{K}, \mathrm{S}, \mathrm{Zn}$ and B fertilizers. The application of MLE significantly improved the growth parameters, yield and yield contributing characters as well as nutrient content and uptake of cabbage. Among the parameters plant height $(33.40 \mathrm{~cm})$, leaf number $(19.33 \mathrm{~cm})$, length of the largest leaf $(29.00 \mathrm{~cm})$, head thickness $(9.67 \mathrm{~cm})$, head diameter $(20.33 \mathrm{~cm})$, gross yield $\left(72.83 \mathrm{t} \mathrm{ha}^{-1}\right)$ and marketable yield (48.87 $\mathrm{t} \mathrm{ha}^{-1}$ ), were maximum in $\mathrm{T}_{4}$ where MLE was sprayed at 2 weeks after transplanting and after every two weeks thereafter. The lowest values of all these parameters were found in $\mathrm{T}_{1}$ where no MLE was sprayed. Foliar application of MLE also improved the concentration and uptake of macronutrients (N, P, K and $\mathrm{S}$ ) in head of cabbage. Thus, application of MLE as a bio-stimulant has the potentiality to enhance growth, yield and nutritional quality of cabbage.
\end{abstract}

Keywords: moringa leaf extract (MLE); bio-stimulant; nutrition; cabbage; growth; yield

\section{Introduction}

Moringa (Moringa oleifera) is a perennial vegetable tree which is found wild and cultivated in many countries of the world including the tropics of Asia, Latin America, and sub-Saharan Africa. In Bangladesh it is grown as a homestead multipurpose tree which has both nutritional and medicinal value. Many researchers have reported that moringa is a highly valued plant having multipurpose effects on plants and animals (Yang et al., 2006; Anwar et al., 2007; Adebayo et al., 2011; Moyo et al., 2011; Mishra et al., 2011). The leaves of moringa contain considerable amount of phytohormones (e.g. cytokinin, gibberellic acid) in addition to other growthpromoting substances such as amino acids, proteins, vitamins, minerals, antioxidants (e.g. ascorbates) and phytochemicals (e.g. phenolics, glucosinolates and isothiocyanates) (Makkar et al., 2007). Now-a-days, natural plant growth bio-stimulants are intensively used for plant growing in normal and stress conditions. The overall effects of all the growth enhancing components in moringa leaf extract (MLE) have made it a novel and marvelous natural bio-stimulant. Interestingly, many recent scientific reports have highlighted that MLE application to plant can provide beneficial nutrient elements, improve antioxidant defense system and enhance 
vegetative as well as reproductive growth resulting in higher yield and economic benefits under stressed and non-stressed situations (Abohassan and Abusuwar, 2018; Prabhu et al., 2010; Aluko et al., 2017; Hala et al., 2017; Merwad, 2017; Matthew, 2016; Emongor, 2015; Rady and Mohamed, 2015; Ozobia, 2014; Mohammed et al., 2013; Abdalla, 2013; Mvumi et al., 2012, 2013).

Vegetables are enriched with different vitamins, minerals, and phytochemicals. Unfortunately, most of the people of Bangladesh suffer from malnutrition due to lack of proper knowledge on balanced diet. According to the FAO recommendation, the amount of consumption of vegetables should be at least $200 \mathrm{~g} / \mathrm{day} / \mathrm{person}$ but the average intake of vegetables by Bangladeshi people is far below the standard (FAO, 2017). Cabbage (Brassica oleracea var. capitata $L$.) is an important cole crop belonging to Brassicaceae family which is cheap and easily grown in our country. It is an economically valuable leafy vegetable that contains a range of essential vitamins, minerals, and amino acids. So, increased cabbage production can contribute to national economy by ensuring nutritional demand of the people. Increased production of vegetable crops can ensure nutritional demand of the country and contribute in national economy. In Bangladesh, the total production of cabbage was 321000 metric tons (BBS, 2018) which is quite low in comparison to cabbage production in many Asian countries like China, Japan, South Korea, India etc.

In our country, the farmers are highly dependent on inorganic fertilizers as a source of plant nutrients and the frequent application of chemical fertilizers is associated with land and soil degradation as well as environmental pollution. Therefore, to improve plant and soil health, it is high time to search for alternative, eco-friendly and safe technology for crop production. To meet up the demand of organic fertilizer, one of such option is use of MLE as fertilizer for crop plants (Davis, 2000). If MLE can increase the growth and yield of vegetable crops like cabbage, it would be beneficial for the smallholder farmers in Bangladesh because MLE is a low-cost, easily available and environment friendly technology. Although a very few literatures cited the effect of MLE on growth and yield of vegetable crops, the application of MLE for agricultural purposes to enhance growth and yield of vegetable crops in Bangladesh has not yet been thoroughly investigated. Therefore, more research work needs to be performed to find out the novel effect of MLE as an organic fertilizer for developing sustainable agricultural practice in Bangladesh. The present study was undertaken to investigate the effect of foliar application of MLE on growth and yield performance of cabbage.

\section{Materials and Methods}

\subsection{Experimental site and soil}

The research work was conducted at the Soil Science Field Laboratory of Bangladesh Agricultural University (BAU), Mymensingh during Rabi season from November 2017 to February 2018. The geographical location of the field is $24^{\circ} 75^{\prime} \mathrm{N}$ latitude and $90^{\circ} 50^{\prime} \mathrm{E}$ longitude at the elevation of $18 \mathrm{~m}$ above the sea level. The land topography was medium high belonging to the Sonatala series of Non-Calcareous Dark Grey Floodplain Soils of AEZ-9 named Old Brahmaputra Floodplain (FAO, 1988). The land was moderately well drained and sufficient sunshine was available throughout the experimental period. The soil was silt loam in texture having pH 6.28, organic matter content $1.12 \%$, total $\mathrm{N} 0.152 \%$, available P $11.08 \mathrm{ppm}$, exchangeable $\mathrm{K} 0.053 \mathrm{me} \%$ and available $S 9.83 \mathrm{ppm}$.

\subsection{Treatments and experimental design}

The experiment was laid out in a randomized complete block design (RCBD) with three replications. The four treatment combinations were $\mathrm{T}_{1}$ Foliar spray with water (control), $\mathrm{T}_{2}$ (MLE foliar spray at 2 weeks after transplanting), $\mathrm{T}_{3}$ (MLE foliar spray at 2 weeks and 4 weeks after transplanting), $\mathrm{T}_{4}$ (MLE foliar spray at 2 weeks after transplanting and after every two weeks thereafter). The experimental area was divided into three blocks representing the replication and each block was subdivided into four-unit plots. The treatments were randomly distributed to the unit plots in each block. The total number of plots was $4 \times 3=12$. The unit plot size was $2.5 \mathrm{~m} \times 2 \mathrm{~m}$. The spacing between blocks was $0.8 \mathrm{~m}$ and the plots were separated from each other by a space of $0.5 \mathrm{~m}$.

\subsection{Seedling transplanting}

In this experiment, cabbage (hybrid variety named Atlas 70) was used as test crop. About 25-days-old cabbage seedlings were transplanted in the experimental plots on the 14th November 2017. The seedlings were uprooted from the seedbed carefully to avoid damage of the root system and transplanted in the afternoon followed by light irrigation for their better establishment. The line to line distance was $60 \mathrm{~cm}$ and plant to plant distance was $50 \mathrm{~cm}$. The young seedlings were provided with shade by banana leaf sheath during daytime to protect from scorching sunshine up to 5 days until their settlement in the soil. The seedlings were kept open at night for 
allowing them to receive dew. A number of extra seedlings were also planted for gap filling on the border of the experimental plots.

\subsection{Fertilizer application}

The full amount of triple super phosphate (TSP), muriate of potash (MoP), gypsum, zinc oxide and boric acid were added during final land preparation as basal dose at the rate of $66,70,24,3$ and $1 \mathrm{~kg} \mathrm{ha}^{-1}$, respectively according to the Fertilizer Recommendation Guide (FRG, 2012). Urea was applied in three installments and the rate was $180 \mathrm{~kg} \mathrm{ha}^{-1}$. The first split was applied as basal during final land preparation, while the second and third split were applied as top dressing at 30 and 45 DAT (days after transplanting), respectively.

\subsection{Collection and preparation of MLE}

Fresh young leaves were collected from matured trees located at different places of Bangladesh Agricultural University Campus, Mymensingh for preparation of MLE. About $100 \mathrm{~g}$ of collected leaves were taken into a mortar with a pinch of water $(10 \mathrm{~mL} / 100 \mathrm{~g}$ fresh material) and ground with a pestle. The juice was extracted by pressing withhand and was filtered through a cheese cloth followed by re-filtering using Whatman filter paper No. 2. Following the method developed by Fuglie, the extract was then diluted with distilled water at a ratio of $1: 32(\mathrm{v} / \mathrm{v})$ and sprayed directly onto the cabbage plants (Fuglie, 2000). The remaining extract was stored at $0^{\circ} \mathrm{C}$ temperature and taken out only when needed for use.

\subsection{Foliar application of MLE in cabbage}

The prepared MLE was sprayed @ $25 \mathrm{~mL}_{\text {plant }}{ }^{-1}$ as per treatments using hand sprayer in the late afternoon with special attention for complete coverage of plants with MLE. In the control plots water was sprayed instead of MLE and special attention was given to avoid drifting of spray materials from one plot to another.

\subsection{Intercultural operations}

Light watering was done by using a watering can at every morning and afternoon following seedling transplanting and was continued for a week for rapid and well establishment of the transplanted seedlings. In the field, flood irrigation was given at 30 DAT and 45 DAT after the establishment of seedlings. Other intercultural operations such as weeding, fencing, gap filling, and application of pesticide were done as and when necessary.

\subsection{Harvesting and data collection}

The crop under investigation was harvested on the 16th February 2018 at full maturity stage. Data on growth and yield parameters such as plant height, leaf number, length, breadth and weight of the largest leaf, weight of root and stem, head thickness, head diameter, head weight, total weight of plant, gross yield and marketable yield were recorded at the time of harvesting.

\subsection{Preparation and analysis of plant samples}

The head samples of cabbage were dried in an oven at $65^{\circ} \mathrm{C}$ temperature for about 48 hours and then ground by a grinding machine to pass through a 20 -mesh sieve. The ground plant materials were stored in paper bags separately, placed in a desiccator and analyzed for determination of macronutrient contents namely $\mathrm{N}, \mathrm{P}, \mathrm{K}$ and $\mathrm{S}$. The total $\mathrm{N}$, available $\mathrm{P}$, exchangeable $\mathrm{K}$ and available $\mathrm{S}$ of plant samples were determined following semimicro Kjeldahl method, modified Olsen method, $\mathrm{NH}_{4} \mathrm{OAc}$ extraction method and $\mathrm{CaCl}_{2}$ extraction method, respectively. After chemical analysis of head samples, the nutrient uptake was calculated from the nutrient content and yield of the crop.

\subsection{Statistical analysis}

The collected data on different parameters were analyzed statistically to get the level of significance using the MSTAT-computer package program (Russell, 1986). The differences among treatment means were compared by Duncan's New Multiple Range Test (DMRT) at 5\% level of probability (Gomez and Gomez, 1984).

\section{Results and Discussion}

\subsection{Effect of MLE on growth parameters of cabbage}

Application of MLE had significant positive effects on growth parameters of cabbage such as plant height, leaf number, length and weight of the largest leaf (Table 1). Treatment $T_{4}$ (MLE foliar spray at 2 weeks after transplanting and after every two weeks thereafter) showed the highest values of plant height $(33.40 \mathrm{~cm})$, leaf number (19.33), length of the largest leaf $(29.00 \mathrm{~cm})$ and weight of the largest leaf $(45.70 \mathrm{~g})$ whereas the lowest 
values of plant height $(29.60 \mathrm{~cm})$, leaf number $(16.67)$, the length of the largest leaf $(24.50 \mathrm{~cm})$ and the weight of the largest leaf $\left(41 \mathrm{~g}\right.$ ) were observed in treatment $\mathrm{T}_{1}$ (control). Foliar application of MLE had no significant effect on other growth parameters viz. leaf breadth and fresh root weight but these parameters were improved with the increase of the frequency of MLE application. The highest values of leaf breadth $(24.30 \mathrm{~cm})$ and fresh root weight $(21.33 \mathrm{~g})$ were recorded from treatment $\mathrm{T}_{4}$. On the other hand, the lowest values of number of leaf breadth $(21.30 \mathrm{~cm})$ and fresh root weight $(19.33 \mathrm{~g})$ were observed in control treatment $\left(\mathrm{T}_{1}\right)$. These results are in agreement with those of many researchers who reported significantly better growth parameters including plant height, weight of shoot, number of leaves etc. in different vegetables and legume crops namely okra, pepper, snap bean, common bean, eggplant and tomato etc. by foliar application of MLE compared to control (Aluko et al., 2017; Hala et al., 2017; Merwad, 2017; Matthew, 2016; Emongor, 2015; Rady and Mohamed, 2015; Ozobia, 2014).

Table 1. Growth parameters of cabbage as influenced by different treatments.

\begin{tabular}{|l|l|l|l|l|l|l|}
\hline Treatments & $\begin{array}{l}\text { Plant height } \\
(\mathbf{c m})\end{array}$ & $\begin{array}{l}\text { Number of } \\
\text { leaf plant }^{-1}\end{array}$ & $\begin{array}{l}\text { Length of the } \\
\text { largest leaf } \\
\text { (cm) }\end{array}$ & $\begin{array}{l}\text { Breadth of the } \\
\text { largest leaf } \\
\text { (cm) }\end{array}$ & $\begin{array}{l}\text { Weight of the } \\
\text { largest leaf } \mathbf{( g )})\end{array}$ & $\begin{array}{l}\text { Fresh } \\
\text { weight of } \\
\text { root } \mathbf{( g )}\end{array}$ \\
\hline T1 & $29.60 \mathrm{~b}$ & $16.67 \mathrm{~b}$ & $24.50 \mathrm{~b}$ & 21.30 & $41.00 \mathrm{~b}$ & 19.33 \\
\hline T2 & $30.73 \mathrm{~b}$ & $18.00 \mathrm{ab}$ & $28.30 \mathrm{a}$ & 22.13 & $42.50 \mathrm{~b}$ & 20.00 \\
\hline T3 & $32.10 \mathrm{ab}$ & $18.67 \mathrm{a}$ & $28.90 \mathrm{a}$ & 23.90 & $45.10 \mathrm{a}$ & 21.33 \\
\hline T4 & $33.40 \mathrm{a}$ & $19.33 \mathrm{a}$ & $29.00 \mathrm{a}$ & 24.30 & $45.70 \mathrm{a}$ & 21.33 \\
\hline CV $(\%)$ & 2.41 & 1.85 & 6.32 & 4.25 & 13.22 & 6.32 \\
\hline Level of sig. & $*$ & $*$ & $* *$ & NS & $*$ & NS \\
\hline
\end{tabular}

In a column, figures with same letters or without letter do not differ significantly whereas figures with dissimilar letter differ significantly as per Duncan's New Multiple Range Test (DMRT). $\mathrm{T}_{1}=$ Control (foliar spray with water), $\mathrm{T}_{2}=$ MLE sprayed at 2 weeks after transplanting, $\mathrm{T}_{3}=$ MLE sprayed at 2 weeks and 4 weeks after transplanting, $\mathrm{T}_{4}=$ MLE sprayed at 2 weeks after transplanting and after every two weeks thereafter $*=$ Significant at $5 \%$ level of probability, $* *=$ Significant at $1 \%$ level of probability, NS $=$ Not significant, $\mathrm{CV}=\mathrm{Co}-$ efficient of variation.

\subsection{Effect of MLE on yield parameters and yield of cabbage}

The foliar application of MLE significantly affected yield parameters and yield of cabbage (Table 2). Head thickness $(\mathrm{cm})$ varied significantly with different MLE treatments. The highest thickness of head $(9.67 \mathrm{~cm})$ was observed in $\mathrm{T}_{4}$ treatment (MLE sprayed at 2 weeks after transplanting and after every two weeks thereafter) which was statistically similar with $\mathrm{T}_{3}$ treatment. The lowest thickness of head $(7.67 \mathrm{~cm})$ was observed in control treatment where no MLE was applied. Head diameter also showed variation with different frequency of MLE application. The highest diameter of head $(20.33 \mathrm{~cm})$ was found in $\mathrm{T}_{4}$ treatment which was statistically similar with $\mathrm{T}_{3}$ treatment whereas the lowest diameter of head $(16.50 \mathrm{~cm})$ was recorded in control treatment. The highest application of MLE $\left(\mathrm{T}_{4}\right)$ showed the maximum gross yield $\left(72.83 \mathrm{t} \mathrm{ha}^{-1}\right)$ as well as marketable yield $\left(48.87 \mathrm{t} \mathrm{ha}^{-1}\right)$. On the contrary, the minimum gross yield $\left(51.07 \mathrm{t} \mathrm{ha}^{-1}\right)$ and marketable yield $\left(32.40 \mathrm{t} \mathrm{ha}^{-1}\right)$ were recorded in $\mathrm{T}_{1}$ (control).

Table 2. Yield parameters and yield of cabbage as influenced by different treatments.

\begin{tabular}{|l|l|l|l|l|}
\hline Treatments & $\begin{array}{l}\text { Head thickness } \\
(\mathbf{c m})\end{array}$ & $\begin{array}{l}\text { Head diameter } \\
(\mathbf{c m})\end{array}$ & $\begin{array}{l}\text { Gross yield } \\
\left(\mathbf{t ~ h a}^{-1}\right)\end{array}$ & $\begin{array}{l}\text { Marketable yield } \\
\left(\mathbf{t ~ h a}^{-1}\right)\end{array}$ \\
\hline $\mathrm{T}_{1}$ & $7.67 \mathrm{~b}$ & $16.50 \mathrm{c}$ & $51.07 \mathrm{c}$ & $32.40 \mathrm{c}$ \\
\hline $\mathrm{T}_{2}$ & $8.93 \mathrm{~b}$ & $18.83 \mathrm{~b}$ & $62.93 \mathrm{~b}$ & $40.17 \mathrm{~b}$ \\
\hline $\mathrm{T}_{3}$ & $9.00 \mathrm{ab}$ & $20.17 \mathrm{a}$ & $71.43 \mathrm{a}$ & $47.66 \mathrm{a}$ \\
\hline $\mathrm{T}_{4}$ & $9.67 \mathrm{a}$ & $20.33 \mathrm{a}$ & $72.83 \mathrm{a}$ & $48.87 \mathrm{a}$ \\
\hline $\mathrm{CV}(\%)$ & 10.34 & 9.90 & 14.33 & 16.82 \\
\hline Level of sig. & $*$ & $*$ & $* *$ & $* *$ \\
\hline
\end{tabular}

In a column, figures with same letters or without letter do not differ significantly whereas figures with dissimilar letter differ significantly as per Duncan's New Multiple Range Test $(\mathrm{DMRT})$. $\mathrm{T}_{1}=$ Control (foliar spray with water), $T_{2}=$ MLE sprayed at 2 weeks after transplanting, $T_{3}=$ MLE sprayed at 2 weeks and 4 weeks after transplanting, $\mathrm{T}_{4}=$ MLE sprayed at 2 weeks after transplanting and after every two weeks thereafter $*=$ Significant at $5 \%$ level of probability, ${ }^{* *}=$ Significant at $1 \%$ level of probability, NS $=$ Not significant, CV $=$ Coefficient of variation. 
The treatments may be ranked in the order of $T_{4}>T_{3}>T_{2}>T_{1}$ for both gross yield and marketable yield. Due to different treatments, the percent increase in gross yield and marketable yield of cabbage over control is shown in Figure 1. The percent increase in gross yield and marketable yield over control ranged from 23.22 to 42.6 and 23.98 to 50.83 respectively. These results are accorded to those of some researchers who suggested $10-45 \%$ increase in crop yield with MLE application (Maishanu et al., 2017). In case of percent increase in gross yield and marketable yield, treatments $\mathrm{T}_{4}$ and $\mathrm{T}_{2}$ gave the highest and the lowest yield increase over control, respectively. From this experiment, it was observed that the yield of the crop was higher with the higher frequency of MLE application during growth stage.

Some researchers reported that presence of zeatin, a cytokinin related hormone in the extract of moringa leaf is responsible for the improved growth and yields of MLE-treated crops (Makkar et al., 2007; Abdalla, 2013; Mvumi et al., 2013). Besides, MLE can also be a source of additional nutrient elements to crops for betterment of growth and yield as moringa leaves are a rich source of essential nutrient elements for plants (Yameogo et al., 2011 and Busani et al., 2011).

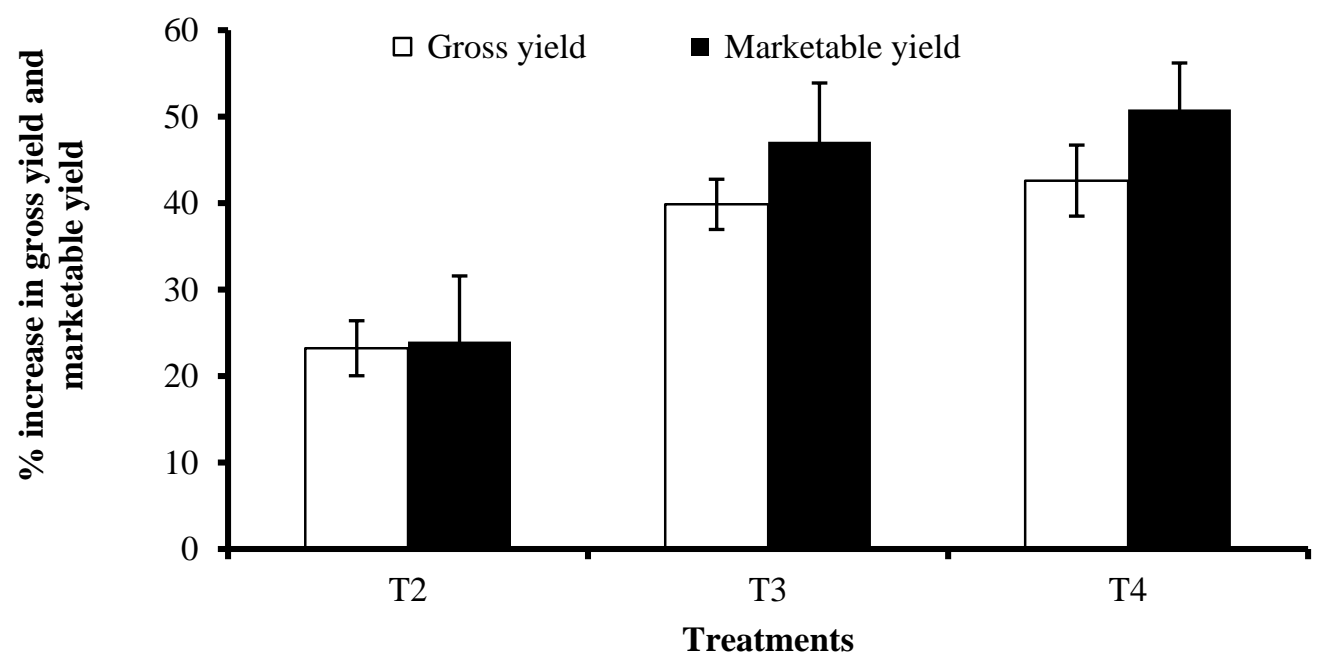

Figure 1. Percent increase in gross yield and marketable yield of cabbage over control under the influence of different treatments.

\subsection{Nutrient content in cabbage head}

Application of MLE showed significant effects on the nutrient content (N, P, K and S) in cabbage head (Table 3 ). The $\mathrm{N}$ content in cabbage head was significantly influenced by MLE application. The highest $\mathrm{N}$ content in cabbage head $(0.20 \%)$ was obtained from $\mathrm{T}_{4}$ treatment (MLE sprayed at 2 weeks after transplanting and after every two weeks thereafter) which was statistically similar with $\mathrm{T}_{3}$ treatment (MLE sprayed at 2 weeks and 4 weeks after transplanting) while the lowest head-N $(0.15 \%)$ was recorded in $\mathrm{T}_{1}$ (control). The $\mathrm{P}$ content of head was positively influenced by MLE application in cabbage. The content of head-P in cabbage was highest $(0.85 \%)$ at $\mathrm{T}_{4}$ treatment being statistically similar with $\mathrm{T}_{3}$ treatment (MLE sprayed at 2 weeks and 4 weeks after transplanting). The lowest $\mathrm{P}$ content in head of cabbage $(0.6 \%)$ was noted in $\mathrm{T}_{1}$ treatment, in which $\mathrm{T}_{1}$ was statistically similar with $\mathrm{T}_{2}$ treatment (MLE sprayed at 2 weeks after transplanting). Application of MLE showed significant effects on $\mathrm{K}$ content of head of cabbage. The highest $\mathrm{K}$ content in cabbage head $(0.20 \%)$ was found in $\mathrm{T}_{4}$ treatment which was statistically similar with $\mathrm{T}_{3}$ treatment. The lowest $\mathrm{K}$ content in head $(0.15 \%)$ was recorded in $\mathrm{T}_{1}$ treatment. There was significant effect of MLE application on S content in head of cabbage. The highest $\mathrm{S}$ content in head $(0.41 \%)$ was observed in $\mathrm{T}_{4}$ treatment which was statistically similar with $\mathrm{T}_{3}$ treatment and the lowest $\mathrm{S}$ content in head $(0.28 \%)$ was noted in $\mathrm{T}_{1}$ treatment which was not statistically different from $\mathrm{T}_{2}$ treatment. 
Table 3. Nutrient contents in cabbage head as influenced by different treatments.

\begin{tabular}{|l|l|l|l|l|}
\hline Treatments & $\mathbf{\%}$ & $\mathbf{N}$ & $\boldsymbol{\%} \mathbf{K}$ & $\mathbf{\%}$ \\
\hline $\mathbf{T}_{\mathbf{1}}$ & $0.15 \mathrm{c}$ & $0.60 \mathrm{~b}$ & $0.15 \mathrm{~b}$ & $0.28 \mathrm{~b}$ \\
\hline $\mathbf{T}_{\mathbf{2}}$ & $0.19 \mathrm{~b}$ & $0.67 \mathrm{~b}$ & $0.18 \mathrm{ab}$ & $0.31 \mathrm{~b}$ \\
\hline $\mathbf{T}_{\mathbf{3}}$ & $0.20 \mathrm{a}$ & $0.78 \mathrm{a}$ & $0.19 \mathrm{a}$ & $0.37 \mathrm{a}$ \\
\hline $\mathbf{T}_{\mathbf{4}}$ & $0.20 \mathrm{a}$ & $0.85 \mathrm{a}$ & $0.20 \mathrm{a}$ & $0.41 \mathrm{a}$ \\
\hline $\mathbf{C V}(\boldsymbol{\%})$ & 11.54 & 15.14 & 7.82 & 16.58 \\
\hline Level of sig. & $* *$ & $* *$ & $* *$ & $* *$ \\
\hline
\end{tabular}

In a column, figures with same letters or without letter do not differ significantly whereas figures with dissimilar letter differ significantly as per Duncan's New Multiple Range Test (DMRT). $\mathrm{T}_{1}=$ Control (foliar spray with water), $T_{2}=$ MLE sprayed at 2 weeks after transplanting, $T_{3}=$ MLE sprayed at 2 weeks and 4 weeks after transplanting, $\mathrm{T}_{4}=$ MLE sprayed at 2 weeks after transplanting and after every two weeks thereafter $* *=$ Significant at $1 \%$ level of probability, NS= Not significant, $\mathrm{CV}=\mathrm{Co}$-efficient of variation.

\subsection{Nutrient uptake by cabbage head}

Like as nutrient contents, application of MLE significantly affected the uptake of nutrients (N, P, K and S) by cabbage head (Table 4). The highest uptake of $\mathrm{N}\left(143.79 \mathrm{~kg} \mathrm{ha}^{-1}\right), \mathrm{P}\left(608.34 \mathrm{~kg} \mathrm{ha}^{-1}\right), \mathrm{K}\left(137.32 \mathrm{~kg} \mathrm{ha}^{-1}\right)$ and $\mathrm{S}\left(\left(291.82 \mathrm{~kg} \mathrm{ha}^{-1}\right)\right.$ by head were obtained from $\mathrm{T}_{4}$ treatment while the lowest uptake of $\mathrm{N}(76.57 \mathrm{~kg}$ $\left.\mathrm{ha}^{-1}\right), \mathrm{P}\left(305.11 \mathrm{~kg} \mathrm{ha}^{-1}\right), \mathrm{K}\left(81.27 \mathrm{~kg} \mathrm{ha}^{-1}\right)$ and $\mathrm{S}\left(141.58 \mathrm{~kg} \mathrm{ha}^{-1}\right)$ were found in $\mathrm{T}_{1}$ (control). In case of nutrient uptake by head, treatment $\mathrm{T}_{4}$ and $\mathrm{T}_{3}$ are statistically similar. Several comparable studies confirmed the current data. Jhilik et al. (2018); Merwad and Abdel-Fattah (2017); Nasir et al. (2016) suggested the increased uptake and accumulation of some macro nutrient elements such as $\mathrm{N}, \mathrm{P}, \mathrm{K}$ and $\mathrm{S}$ in several plants as a consequence of organic fertilization from MLE. As the leaves of moringa plant have been reported to be a rich source of important nutrient elements (Yameogo et al., 2011 and Moyo et al., 2011), the extract of leaves i.e. MLE can boost plants to uptake progressively beneficial elements, to increase the nutrient status and eventually to attain optimum growth and productivity.

Table 4. Nutrient uptake by cabbage head as influenced by different treatments.

\begin{tabular}{|l|l|l|l|l|}
\hline Treatments & $\begin{array}{l}\mathbf{N} \text { uptake } \\
\left(\mathbf{k g ~ h a}^{-1}\right)\end{array}$ & $\begin{array}{l}\mathbf{P}_{\text {uptake }} \\
\left(\mathbf{k g ~ h a}^{-1}\right)\end{array}$ & $\begin{array}{l}\text { K uptake } \\
\left(\mathbf{k g ~ h a}^{-1}\right)\end{array}$ & $\begin{array}{l}\text { S uptake } \\
\left(\mathbf{k g ~ h a}^{-1}\right)\end{array}$ \\
\hline $\mathbf{T}_{\mathbf{1}}$ & $76.57 \mathrm{c}$ & $305.11 \mathrm{c}$ & $81.27 \mathrm{c}$ & $141.58 \mathrm{c}$ \\
\hline $\mathbf{T}_{\mathbf{2}}$ & $118.97 \mathrm{~b}$ & $423.73 \mathrm{~b}$ & $113.76 \mathrm{~b}$ & $194.95 \mathrm{~b}$ \\
\hline $\mathbf{T}_{\mathbf{3}}$ & $142.71 \mathrm{a}$ & $570.30 \mathrm{a}$ & $137.25 \mathrm{a}$ & $270.85 \mathrm{a}$ \\
\hline $\mathbf{T}_{\mathbf{4}}$ & $143.79 \mathrm{a}$ & $608.34 \mathrm{a}$ & $137.32 \mathrm{a}$ & $291.82 \mathrm{a}$ \\
\hline CV $(\%)$ & 3.23 & 8.98 & 3.82 & 8.46 \\
\hline Level of sig. & $* *$ & $* *$ & $* *$ & $* *$ \\
\hline
\end{tabular}

In a column, figures with same letters or without letter do not differ significantly whereas figures with dissimilar letter differ significantly as per Duncan's New Multiple Range Test (DMRT). $\mathrm{T}_{1}=$ Control (foliar spray with water), $T_{2}=$ MLE sprayed at 2 weeks after transplanting, $T_{3}=$ MLE sprayed at 2 weeks and 4 weeks after transplanting, $\mathrm{T}_{4}=$ MLE sprayed at 2 weeks after transplanting and after every two weeks thereafter, $* *=$ Significant at $1 \%$ level of probability, NS= Not significant, $\mathrm{CV}=$ Co-efficient of variation.

\section{Conclusions}

Natural plant growth stimulants are eco-friendly in nature and are intensively studied to improve crop performance under field conditions. This experiment suggests that foliar use of MLE in cabbage had significant positive effects on growth parameters such as plant height, leaf number, length and weight of the largest leaf etc. As a bio-stimulant, MLE application significantly improved various yield components viz. head thickness and diameter and also total weight of plant resulting in a remarkable increase in gross and marketable yield of the vegetable crop. MLE also significantly improved the content and uptake of different nutrients such as N, P, K and $S$ in cabbage. Importantly, the yield of cabbage increased with the higher frequency of MLE application during the growth stage of crop. In conclusion, cabbage fertilized with MLE at 2 weeks after transplanting and after every two weeks thereafter is a promising practice for higher growth and yield and therefore, farmers can practice MLE application at growth stages of vegetable crops especially low yielding varieties for better 
performance. However, further research in other crops is necessary to delineate the effect of MLE and its use as a sustainable agricultural practice in Bangladesh.

\section{Acknowledgements}

The second author acknowledges the support from Ministry of Science and Technology to conduct this research as NST Fellow.

\section{Conflict of interest}

None to declare.

\section{References}

Abdalla MM, 2013. The potential of Moringa oleifera extract as a biostimulant in enhancing the growth, biochemical and hormonal contents in rocket (Eruca vesicaria subsp. sativa) plants. Int. J. Plant Physiol. Biochem., 5: 42-49.

Abohassan RA and AO Abusuwar, 2018. Effects of Moringa olifera leaf extracts on growth and productivity of three leguminous crops. Legume Res., 41: 114-119.

Adebayo AG, HA Akintoye, OO Olufolaji, MT Aina, MT Olatunji and AO Shokalu, 2011. Assessment of organic amendments on vegetative development and nutrient uptake of Moringa oleifera Lam. in the nursery. Asian J. Plant Sci., 10: 74-79.

Aluko M, OJ Ayodele, AS Gbadeola and IH Oni, 2017. Comparative effects of varying rates of moringa leaf, poultry manure and NPK fertilizer on the growth, yield and quality of okra (Abelmoschus esculentus L. Moench). Int. J. Environ. Agric. Biotech., 2: 2901-2907.

Anwar F, S Latif, M Ashraf and AH Gilani, 2007.Moringa oleifera: A food plant with multiple medicinal uses. Phytother. Res., 21: 17-25.

BBS, 2018. Yearbook of Agricultural Statistics-2018. Bangladesh Bureau of Statistics, Statistics and Informatics Division, Ministry of Planning, Government of the People's Republic of Bangladesh, Dhaka, pp. 290.

Busani M, JM Patrick, H Arnold and M Voster, 2011. Nutritional characterization of moringa (Moringa oleifera L am.) leaves. Afr. J. Biotechnol., 10: 12925-12933.

Davis K, 2000. The Moringa Tree, (Revised edition). ECHO, 1739, FL, USA.

Emongor V, 2015. Effects of moringa (Moringa oleifera) leaf extract on growth, yield and yield components of snap beans (Phaseolus vulgaris). Br. J. Appl. Sci. Technol., 6: 114-122.

FAO (Food and Agriculture Organization), 1988. Land Resources Appraisal of Bangladesh for Agricultural Development. Report 2. Agro- ecological Regions of Bangladesh. pp. 212-221.

FAO (Food and Agriculture Organization), 2017. Fruit and vegetables for heath initiative, report of a joint FAO/WHO expert consultation. pp. 2.

FRG (Fertilizer Recommendation Guide), 2012. Fertilizer Recommendation Guide- 2012. Bangladesh Agricultural Research Council, Farmgate, Dhaka.

Fuglie LJ, 2000. The Miracle Tree: Moringaoleifera: Natural nutrition for the Tropics. CTA, Wageningen, The Netherlands.

Gomez KA and AA Gomez, 1984. Statistical Procedures for Agricultural Research. John Wiley \& Sons, New York.

Hala H, A El-Noor and NA Ewais, 2017. Effect of Moringa oleiferaleaf extract (MLE) on pepper seed germination, seedlings improvement, growth, fruit yield and its quality. Middle East J. Agric. Res., 6(2): 448463.

Jhilik NJ, TS Hoque, AZM Moslehuddin and MA Abedin, 2018. Nutritional improvement of wheat by foliar application of moringa leaf extract. Fundam. Appl. Agric., 3: 565-572.

Maishanu HM, MM Mainasara, S Yahaya and A Yunusa, 2017. The use of moringa leaves extract as a plant growth hormone on cowpea (Vigna anguiculata). Path Sci., 3: 3001-3006.

Makkar HPS, G Francis and K Becker, 2007. Bioactivity of phytochemicals in some lesser-known plants and their effects and potential applications in livestock and aquaculture production systems. Anim. Feed Sci. Technol., 1: 1371-1391.

Matthew A, 2016. Moringa leaf extract on the growth and yield of pepper (Capsicum annuumL.). ARPN J. Agric. Biol. Sci., 11: 107-109.

Merwad ARMA, 2017. Using Moringa oleifera extract as biostimulant enhancing the growth, yield and nutrients accumulation of pea plants. J. Plant Nutr., 41: 425-431. 
Merwad ARMA and MK Abdel-Fattah, 2017. Improving productivity and nutrients uptake of wheat plants using moringa oleifera leaf extract in sandy soil. J. Plant Nutr., 40: 1397-1403.

Mishra G, P Singh, R Verma, S Kumar, S Srivastava, KK Jha and RL Khosa, 2011. Traditional uses, phytochemistry and pharmacological properties of Moringa oleifera plant: An overview. Der Pharm. Lett., 3: 141-164.

Mohammed R, M Olorukooba, M Akinyaju and E Kambai, 2013. Evaluation of different concentrations and frequency of foliar application of moringa extract on growth and yield of onion, Allium cepa Lam. Agro search, 13: 196-205.

Moyo B, PJ Masika, A Hugo and V Muchenje, 2011. Nutritional characterization of Moringa (Moringa oleifera Lam.) leaves. Afr. J. Biotechnol., 10: 12925-12933.

Muhamman MA, BM Auwalu, AA Manga and JM Jibrin, 2013. Effects of aqueous extract of moringa (Moringa oleifera Lam.) and nitrogen rates on some physiological attributes and yield of tomato.Int. J. Chem. Environ. Biol. Sci., 1: 67-74.

Mvumi C, F Tagwira and AZ Chiteka, 2012. Effect of moringa extracts on growth and yield of tomato. Greener J. Agric. Sci., 2: 207-211.

Mvumi C, F Tagwira and AZ Chiteka, 2013. Effect of moringa extracts on growth and yield of maize and common beans. Greener J. Agric. Sci., 3: 55-62.

Nasir M, AS Khan, SA Basra and AU Malik, 2016. Foliar application of moringa leaf extract, potassium and zinc influence yield and fruit quality of 'Kinnow' mandarin. Sci. Hortic., 210: 227-235.

Ozobia AP, 2014. Comparative assessment of effect of moringa extracts, NPK fertilizer and poultry manure on soil properties and growth performance of Solanum menlongina in Abuja, North Central Region of Nigeria. J. Agric. Crop Res., 2: 88-93.

Prabhu MA, AR Kumar and K Rajamani, 2010. Influence of different organic substances on growth and herb yield of sacred basil (Ocimum sanctum L.). Indian J. Agric. Res., 44: 48-52.

Rady MM and GF Mohamed, 2015. Modulation of salt stress effects on the growth, physiochemical attributes and yields of Phaseolus vulgaris L. plants by the combined application of salicylic acid and Moringa oleifera leaf extract. Sci. Hortic., 193: 105-113.

Russel DF, 1986. MSTAT-C package programme.Crop and Soil Science, Department, Michigan State University, USA.

Yameogo CW, MD Bengaly, A Savadogo, PA Nikiema and SA Traore, 2011. Determination of chemical composition and nutritional values of Moringa oleifera leaves. Pak. J. Nutr., 10: 264-268.

Yang RY, LC Chang, JC Hsu, BBC Weng, MC Palada, ML Chadha and V Levasseur, 2006. Nutritional and functional properties of moringa leaves-from germplasm, to plant, to food, to health. In: "Moringa and other highly nutritious plant sources: strategies, standards and markets for a better impact on nutrition in Africa, Accra, Ghana". pp. 1-9. 